University of Nebraska - Lincoln

DigitalCommons@University of Nebraska - Lincoln

USDA Forest Service / UNL Faculty Publications U.S. Department of Agriculture: Forest Service -National Agroforestry Center

1997

\title{
Characterization of the replication cycle of the Lymantria dispar nuclear polyhedrosis virus
}

Christopher I. Riegel

USDA Forest Service

James M. Slavicek

USDA Forest Service

Follow this and additional works at: https://digitalcommons.unl.edu/usdafsfacpub

Part of the Forest Sciences Commons

Riegel, Christopher I. and Slavicek, James M., "Characterization of the replication cycle of the Lymantria dispar nuclear polyhedrosis virus" (1997). USDA Forest Service / UNL Faculty Publications. 138. https://digitalcommons.unl.edu/usdafsfacpub/138

This Article is brought to you for free and open access by the U.S. Department of Agriculture: Forest Service -National Agroforestry Center at DigitalCommons@University of Nebraska - Lincoln. It has been accepted for inclusion in USDA Forest Service / UNL Faculty Publications by an authorized administrator of DigitalCommons@University of Nebraska - Lincoln. 


\title{
Characterization of the replication cycle of the Lymantria dispar nuclear polyhedrosis virus
}

\author{
Christopher I. Riegel ${ }^{1}$, James M. Slavicek * \\ USDA Forest Service, Northeastern Forest Experiment Station, Forestry Sciences Laboratory, 359 Main Road, Delaware, \\ OH 43015, USA
}

Received 27 February 1997; received in revised form 18 June 1997; accepted 19 June 1997

\begin{abstract}
The life cycle of the Lymantria dispar nuclear polyhedrosis virus ( $L d M N P V)$ was characterized through analysis of budded virus (BV) release, the temporal formation of polyhedra, the temporal transcription pattern of representative early, late, and hyper-expressed late genes, and the onset of DNA replication in the Ld652Y cell line. Transcripts from the LdMNPV immediate early gene G22 were detected $4 \mathrm{~h}$ post infection (h p.i.). The late and hyper-expressed late p39 capsid and polyhedrin genes were initially transcribed at approximately 20 and $24 \mathrm{~h} \mathrm{p}$.i., respectively. Viral DNA replication initiated at approximately $18-20 \mathrm{~h}$ p.i. Budded virus was released from infected cells between 24 and 36 h p.i., and polyhedra were first detected at approximately 48 h p.i. (C) 1997 Elsevier Science B.V.
\end{abstract}

Keywords: Baculovirus; Lymantria dispar nuclear polyhedrosis virus; Virus life cycle; Lymantria dispar; DNA replication

\section{Introduction}

Nuclear polyhedrosis viruses (NPVs) are members of the Baculoviridae. The genomes of NPVs are composed of covalently closed circular DNA ranging from approximately 80 to $165 \mathrm{~kb}$ in length. The Autographa californica nuclear polyhedrosis virus (AcMNPV) is the best character-

\footnotetext{
* Corresponding author.

${ }^{1}$ Present address. Department of Biology, Ferris State University, 820 Campus Drive, Big Rapids, MI 49 307, USA.
}

ized NPV. These viruses go through a two-stage life cycle (for review see Blissard and Rohrmann, 1990). Early after infection a nonoccluded form of the virus is produced, termed budded virus (BV), which buds from the infected cells and spreads systemically through the larvae infecting other cells. Later in the course of infection, infected cells begin producing occluded virions. These virions are packaged in protein matrices composed almost entirely of the protein polyhedrin to form structures termed polyhedra. Polyhedra are re- 
sponsible for the transmission of the virus to other larvae after the infected host dies.

After entry into the cell, viral DNA is released and is replicated in the nucleus. Viral gene expression is controlled by a regulatory cascade in which each successive phase is dependent upon the previous phase. This cascade includes early, late, and very late (or hyper-expressed) phases. Early gene expression precedes DNA replication, and is divided into immediate early and delayed early phases. Viral genes expressed during the immediate early time period (e.g., the AcMNPV ic-l gene. Guarino and Summers, 1986) require no virally encoded proteins for their efficient expression, and predominately utilize promoters that contain a functional TATA box. The delayed early phase of gene expression initiates at approximately $3 \mathrm{~h}$ p.i. in AcMNPV, and includes the gp64 (Blissard and Rohrmann. 1991), 39K (Guarino and Summers, 1986), and the $p 35 K$ (Nissen and Friesen, 1989) genes. These genes also contain functional TATA boxes that support transcription at basal levels. However, for efficient transcription the delayed early genes $p 35 K, 39 K$, and gp64 require transactivation by the $i e-1$ gene product (Guarino and Summers, 1986; Nissen and Friesen, 1989; Blissard and Rohrmann, 1991; Glocker et al.. 1992). After DNA replication has begun, late expression generates proteins such as the p39 capsid protein (Thiem and Miller, 1989) and polyhedral envelope protein (Gombart et al., 1989). Finally the hyper-expressed or very late phase occurs, during which the polyhedrin and $p 10$ genes are expressed (reviewed by Rohrmann, 1992).

Nuclear polyhedrosis viruses have been isolated from over 600 insect species (David, 1975; Tinsley and Harrap, 1978; Harrap and Payne, 1979). The Lymantria dispar multinucleocapsid nuclear polyhedrosis virus (LdMNPV) is one of these and is pathogenic to the gypsy moth ( $L$. dispar), a serious forest and urban tree defoliator. The Ld $M N P V$ appears to be significantly different from the type baculovirus, AcMNPV. The genome of the LdMNPV is approximately $162 \mathrm{~kb}$ in length and has a $\mathrm{G}+\mathrm{C}$ content of $60 \%$, whereas AcMNPV has $\approx 134 \mathrm{~kb}$ genome with a $\mathrm{G}+\mathrm{C}$ content of $41 \%$ (Ayres et al., 1994). The genes present in the genomes of these viruses are organized in a similar order in short segments, but overall the organization is not collinear (Bjornson and Rohrmann, 1992a,b; Riegel et al., 1994; Bischoff and Slavicek, 1994). Zanotto et al. (1993) have carried out a phylogenetic analysis of the polyhedrin sequences of baculoviruses. This analysis indicates that the $\mathrm{Ld} M N \mathrm{NP}$ is evolutionarily more distant from AcMNPV than all other NPVs pathogenic for lepidoptera investigated. The life cycles of these viruses are similar; however, replication in the Ld $M$ NPV appears to be delayed relative to replication in the AcMNPV since polyhedra are not formed until $\approx 48 \mathrm{~h}$ after infection (this report), compared to $12 \mathrm{~h}$ in AcMNPV. A previous study with a single isolate of $\operatorname{Ld} M N P V$ (McClintock et al., 1986) showed that LdMNPV infections were slower than AcMNPV infections. However, this study considered overall protein synthesis levels and not the now better understood expression-cascade life cycle of baculoviruses.

The $\mathrm{Ld} M \mathrm{NPV}$ is not as well characterized as the AcMNPV. The viral genome has been mapped with restriction endonucleases (Smith et al., 1988; Riegel et al., 1994), and transcription and translation maps have been generated (Slavicek, 1991). A number of genes that have been previously identified in the AcMNPV including the ecdysteroid UDP-glucosyl transferase (Riegel et al., 1994), DNA polymerase (Bjornson et al., 1992), polyhedral envelope protein (Bjornson and Rohrmann, 1992a), polyhedrin (Smith et al.. 1988), p39 nucleocapsid (Bjornson and Rohrmann, 1992b), and viral protein kinase (Bischoff and Slavicek, 1994), have been located and characterized in the LdMNPV. Even though several LdMNPV genes have been characterized at the structural level the life cycle of this virus had not been detailed. In this study we have continued the characterization of $\mathrm{Ld} M$ NPV by describing the viral life cycle through examination of $\mathrm{BV}$ release, the appearance of polyhedra, the onset of DNA replication, and the transcription of genes involved in each of the three stages of viral gene expression. 


\section{Materials and methods}

\subsection{Maintenance of cells and virus}

All virus growth was carried out in $L$. dispar 652Y (Ld652Y) cell line. Cells were grown in Goodwins IPL52B media (JRH Biosciences) supplemented with $10 \%$ heat-inactivated fetal bovine serum (Hyclone), and $6.0 \mathrm{mM}$ glutamine (Gibco). Plaque purified LdMNPV strains A21-2 and B211 , which are genotypic variants, were used for these studies (Slavicek et al., 1995).

\subsection{Detection of polyhedra and virus titration}

Tissue culture flasks $\left(25 \mathrm{~cm}^{2}\right)$ were seeded with $1.25 \times 10^{6} \mathrm{Ld} 652 \mathrm{Y}$ cells, and the cells were infected with isolates A21-2 or B21-1 at 10 TCID $_{50}$ units per cell. At various time points post infection (p.i.), cells were visually inspected by phase contrast microscopy (Nikon Diaphot) to detect the presence of polyhedra, virus-containing media was harvested and titrated by end-point dilution assay, and flasks were harvested and the number of cells quantitated to determine the number of cells per $\mathrm{ml}$ and the number of cells containing polyhedra per $\mathrm{ml}$. These numbers were then used to calculate the percent of cells with polyhedra. After a two week incubation period titration plates were scored and the BV titer was expressed as the $\mathrm{TCID}_{50}$ per $\mathrm{ml}$ of cell culture media.

\subsection{Measuring RNA expression}

Tissue culture flasks $\left(75 \mathrm{~cm}^{2}\right)$ were seeded with $6 \times 10^{6}$ Ld652Y cells, and then infected with Ld $M$ NPV isolate $\mathrm{A} 21-2$ or $\mathrm{B} 21-1$ at $10 \mathrm{TCID}_{50}$ units per cell at $27^{\circ} \mathrm{C}$. After $1 \mathrm{~h}$, the inoculum was replaced with $15 \mathrm{ml}$ of fresh media. One flask of cells per isolate was harvested at $0,4,16,20,24$, 30 , and $48 \mathrm{~h}$ p.i. (counted from the end of the $1 \mathrm{~h}$ adsorption period). Total cytoplasmic RNA was isolated following the procedure of Friesen and Miller (1985). RNA was separated on a $1.2 \%$ agarose gel containing formaldehyde, and the RNA was then transferred to nitrocellulose. Blots were probed with three different LdMNPV probes: G22, an immediate early gene (Bischoff and Slavicek, 1995); p39 capsid, a late gene (Thiem and Miller, 1989; Bjornson and Rohrmann, 1992b); and polyhedrin, a hyper-expressed late gene (Smith et al., 1988; Friesen and Miller, 1985). Strand-specific oligonucleotides were end-labeled with $\left[\gamma-{ }^{32} \mathrm{P}\right] \mathrm{ATP}(\mathrm{NEN})$, and used as probes to detect G22, p39 capsid, and polyhedrin gene transcripts. The following oligonucleotides were used as probes: for the G22 gene, CGTCATGGACAGAGACAGATGCTCGCGAGG; the p39 capsid gene, GGTGGACAGCGCCCCGCTCACAAGTGCCAT; and the polyhedrin gene, GGCGGGGCTGTAGTTGTAAAAGTTGTGCAT. These probes were individually hybridized to the Northern blots and washed according to the phosphate buffer procedure of Mahmoudi and Lin (1989). To investigate temporal transcription of the DNA polymerase gene, a similar time course was set up using only Ld $M$ NPV isolate A21-2 and RNA was harvested at $12,14,16,18,20,22$, and $24 \mathrm{~h}$ p.i.. DNA polymerase gene transcripts were detected using a $N d e$ I to $B g l \mathrm{II} 3.0 \mathrm{~kb}$ fragment from the genomic region of 87 to $90 \mathrm{~kb}$ that contains most of the LdMNPV DNA polymerase gene (Bjornson and Rohrmann, 1992b) as a probe that was labeled by nick-translation with $\left[\alpha{ }^{32} \mathrm{P}\right]$ dCTP (NEN). DNA polymerase gene transcripts were also detected by reverse transcription and subsequent polymerase chain reaction (PCR) amplification according to the manufacturers protocol (Perkin Elmer). The reverse transcription and downstream PCR primer was composed of the nucleotides of the DNA polymerase gene from position 4042 to 4059 , and the upstream primer was composed of the nucleotides from position 3481 to 3498 (Bjornson et al., 1992).

\subsection{Detecting the onset of DNA replication}

Six well plates (Corning) were seeded with $1.8 \times 10^{6} \mathrm{Ld} 652 \mathrm{Y}$ cells per well. The cells were inoculated with $10 \mathrm{TCID}_{50}$ units/cell of LdMNPV isolate $\mathrm{A} 21-2$ or $\mathrm{B} 21-1$, and infection was allowed to proceed for $1 \mathrm{~h}$. The virus was then replaced with fresh media. One well of cells was harvested at $0,6,12,16,18,20,22,24,26,28,32,36$, and $48 \mathrm{~h}$ p.i. (counting from the end of the $1 \mathrm{~h}$ 
adsorption period) for each of the two isolates. Cells were harvested by scraping the cells from the bottom of the well with a cell scraper, resuspending the cells in the BV-containing media, and transferring the cells and the media to a $15 \mathrm{ml}$ Corning tube. The cells were then lysed by freezing overnight at $-20^{\circ} \mathrm{C}$. DNA was extracted from the cells by the method of Strauss (1990). One $\mathrm{ml}$ of cell suspension was made $100 \mathrm{mM}$ $\mathrm{NaCl}, 10 \mathrm{mM}$ Tris- $\mathrm{HCl}, \mathrm{pH} 8.0,25 \mathrm{mM}$ EDTA, $0.5 \% \mathrm{SDS}, 0.1 \mathrm{mg} / \mathrm{ml}$ proteinase $\mathrm{K}$ (BoehringerMannheim), $0.1 \mathrm{mg} / \mathrm{ml}$ RNase A (Sigma), and then incubated overnight at $50^{\circ} \mathrm{C}$ (shaking). The cell suspension was then extracted twice with phenol/chloroform/isoamyl alcohol (25:24:1), and the aqueous phase was precipitated with sodium acetate and ethanol. The pellet was resuspended in $400 \mu 1$ of $6 \times$ SSC and quantitated by UV spectroscopy. The DNA was checked on a $1 \%$ agarose gel for the presence of RNA. Three dot blots were generated via the method of Brown (1991) using 1 $\mu \mathrm{g}$ of each DNA. These blots were then probed with a nick-translated probe for the p39 gene which contained only coding regions for the p39 gene. The blots were hybridized and washed according to the method of Mahmoudi and Lin (1989), and five exposures ( $10 \mathrm{~min}, 1 \mathrm{~h}, 3 \mathrm{~h}, 6 \mathrm{~h}$, and $16 \mathrm{~h}$ ) were made on Kodak XAR 5 X-ray film using intensifying screens. The developed autoradiograms were quantitated using a Biorad model 620 video densitometer. By comparing different exposures it was possible to generate non-saturating signals for each of the time points.

\section{Results and discussion}

\subsection{Release of $B V$ and polyhedron synthesis}

The studies performed in this investigation were done with two plaque purified Ld $M$ NPV genotypic variants, isolates A21-2 and B21-1, (Slavicek et al., 1995), to assure that the observations were representative of LdMNPV as opposed to a viral variant. A multiplicity of infection (m.o.i.) of 10 was chosen for this study since essentially all cells exhibited a typical cytopathic effect at $24 \mathrm{~h}$ p.i. $\mathrm{BV}$ and polyhedron formation were investigated during a 10-day and 7 day time course, respectively. The onset of $\mathrm{BV}$ release occurred at approximately $24 \mathrm{~h}$ p.i. (Fig. 1A). BV release continued through $\approx 72 \mathrm{~h}$ p.i., and the amount of BV present remained essentially constant through 8 days p.i. (Fig. 1B). The greatest increase in the amount of BV present occurred from 20 to $48 \mathrm{~h}$ p.i. Polyhedra were first detected on the second day p.i. in both isolates by visual inspection, using phase contrast microscopy. The percentage of cells containing polyhedra increased through 7

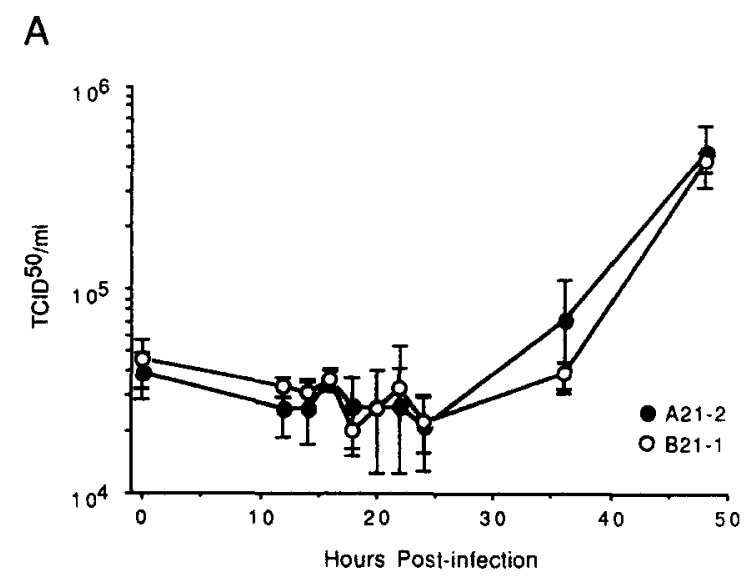

B

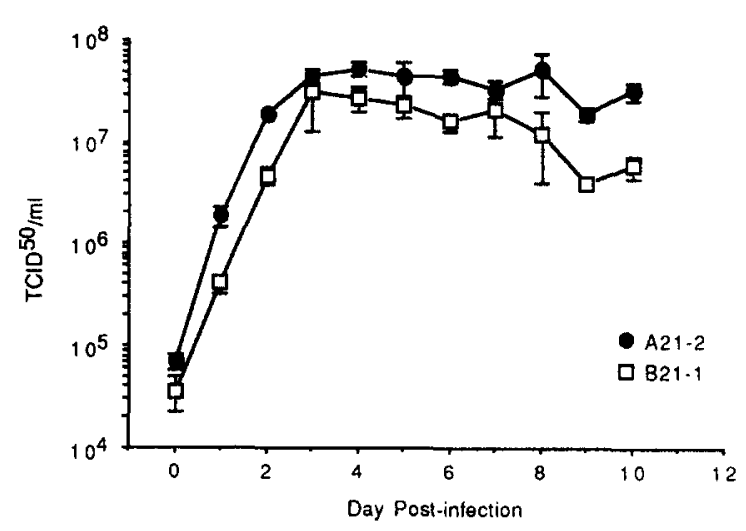

Fig. 1. Budded virus (BV) production in Ld652Y cells. Ld652Y cells were infected at $10 \mathrm{TCID}_{50}$ units per cell. The cell culture media was harvested at $0-48 \mathrm{~h}$ p.i. (A) and $0-10$ days p.i. (B). BV $\mathrm{TCID}_{50}$ values were determined by the end-point dilution assay. Each value is the average of three determinations. The standard deviations of the means are indicated by the bars. 


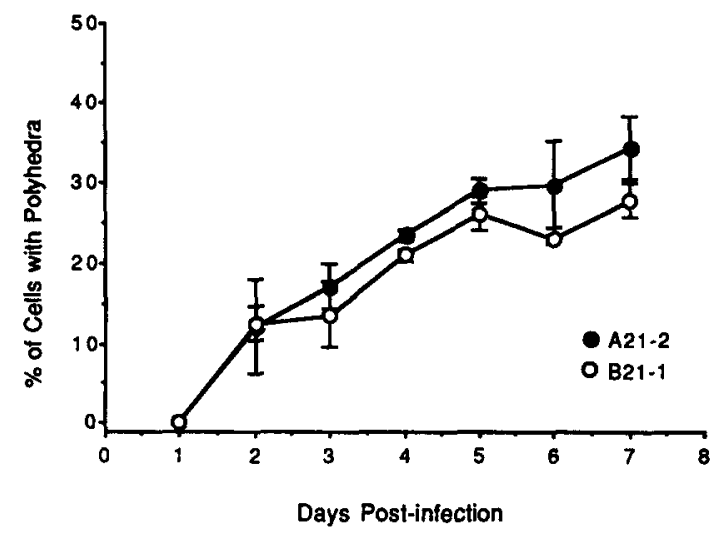

Fig. 2. Synthesis of polyhedra during viral infection of Ld652Y cells. The percentage of cells containing polyhedra was determined by light microscopic examination of $\approx 200$ cells at each time point. Each value is an average of three determinations, and one standard deviation is shown.

days p.i., and $\approx 30 \%$ of the cells contained polyhedra at the last time point analyzed (Fig. 2).

\subsection{Temporal transcription of early, late, and hyper-expressed genes}

The temporal expression of an RNA from each of the three temporal classes (early, late, and hyper-expressed late) was examined by Northern analysis of RNA isolated from isolates A21-2 and B21-1. The immediate early gene, G22, was identified in a previous investigation on $\operatorname{Ld} M$ NPV spatial and temporal transcription (Slavicek, 1991). G22 gene transcripts are first detected after a 1-h adsorption period, and are expressed in the presence of cycloheximide (Bischoff and Slavicek, 1995), indicating that viral protein synthesis is not required for its expression. Consequently, the G22 gene was classified as an early gene, and was used in this investigation to represent the early class of viral genes. Northern blots of RNA collected from both isolates at $0,4,16,24$, and $48 \mathrm{~h}$ p.i. were probed with a G22 gene specific probe. A transcript of approximately 850 nucleotides was found in both isolates (Fig. 3A). This transcript was detected at $4 \mathrm{~h}$ p.i. and it was still present at $30 \mathrm{~h}$ p.i. The $4 \mathrm{~h}$ p.i. sample of isolate $\mathrm{A} 21-2$ contains more $\mathrm{G} 22$ gene transcripts than the same time point of isolate B21-1. However, in an addi- tional time course analysis of G22 gene transcription no difference was found between the isolates (data not shown). The Ld $M$ NPV p39 capsid gene was used to represent the late class of viral genes (Bjornson and Rohrmann, 1992b). A p39 capsid gene specific probe detected a single transcript of $\approx 1350$ nucleotides initially at $20 \mathrm{~h}$ p.i. in both $\mathrm{Ld} M$ NPV isolates (Fig. 3B). The greatest amount of p39 capsid gene transcripts were present at 48 h p.i. compared to the other times assayed. The polyhedrin gene was used to represent the very late class of $\mathrm{Ld} M \mathrm{NPV}$ genes. A polyhedrin gene specific probe first detected transcripts of approximately 1400 and 3100 nucleotides at $30 \mathrm{~h}$ p.i. in both Ld $M$ NPV isolates (Fig. 3C). The amount of polyhedrin gene transcripts present at $48 \mathrm{~h}$ p.i. was much greater than at $30 \mathrm{~h}$ p.i.

\subsection{Onset of DNA replication}

Total DNA was isolated from cells infected with the Ld $M$ NPV isolates at $0,6,12,16,18,20$, $22,24,26,28,32,36,42$, and 48 h p.i. Triplicate dot blots were generated using $1 \mu \mathrm{g}$ of DNA from each time point. These blots were hybridized to a viral DNA probe (p39 capsid gene) and repetitively exposed to X-ray film for $10 \mathrm{~min}, 1 \mathrm{~h}, 3 \mathrm{~h}$, $6 \mathrm{~h}$, and $16 \mathrm{~h}$. Signals from the linear range from each of the exposures were normalized to the value they would have had with a 1-h exposure by comparing densities for points that were linear on each of two exposures. Densities were then averaged for all three blots. The relative density of each point was then determined with respect to the highest density for that isolate. The relative densities are plotted in Fig. 4. Both LdMNPV isolates exhibited a very similar DNA replication time course. By 20 h p.i. the relative density has doubled from the initial density indicating that DNA replication had begun. An increase in viralspecific DNA of approximately 3 fold occurred between 12 and $24 \mathrm{~h}$ p.i. A greater increase in viral DNA, of approximately 20 -fold, occurred between 24 and $48 \mathrm{~h}$ p.i. (Fig. 4). This result is in close agreement with the observed 23 fold increases in BV found from 24 to $48 \mathrm{~h}$ p.i. (Fig. 1A). 


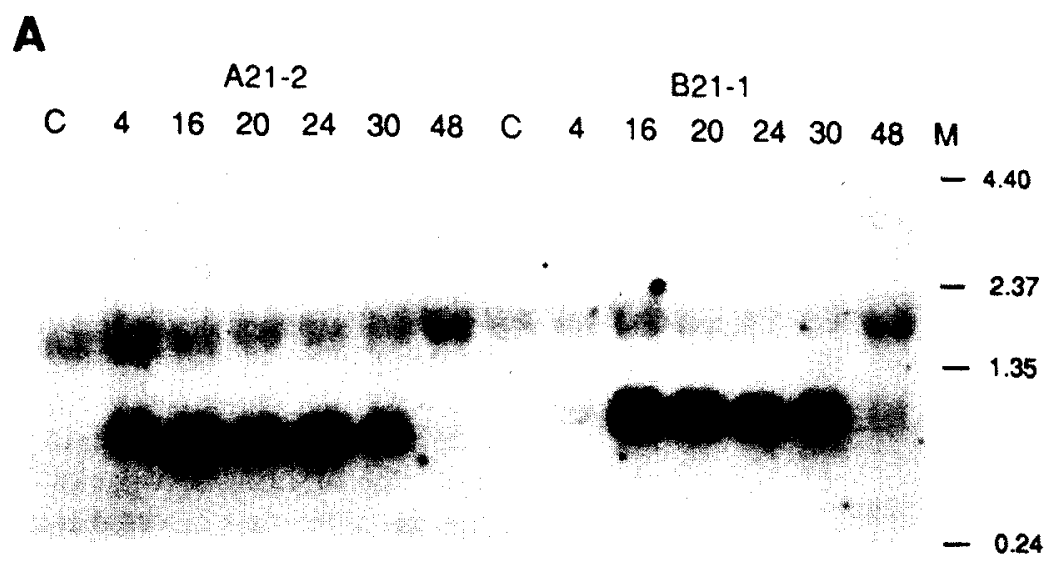

B

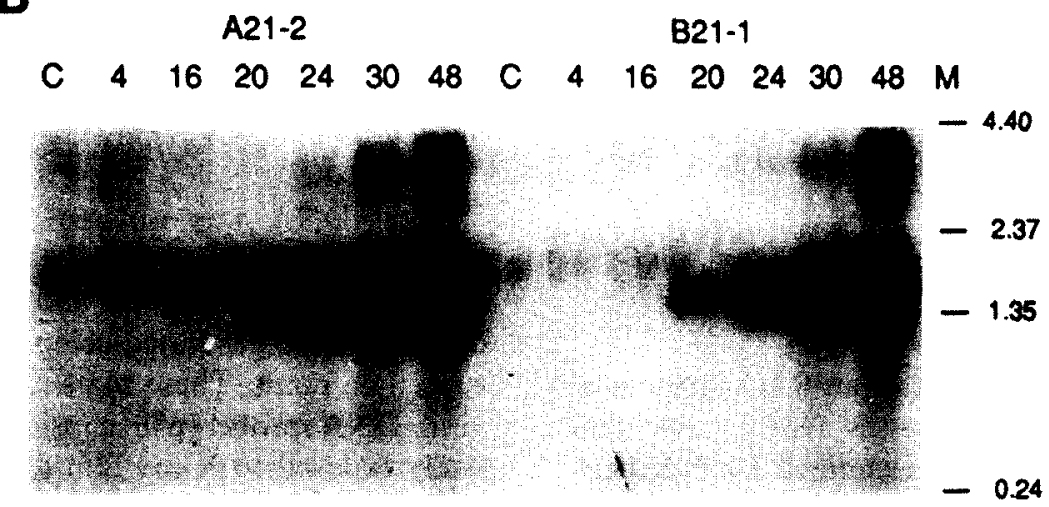

C

A21-2

B21-1

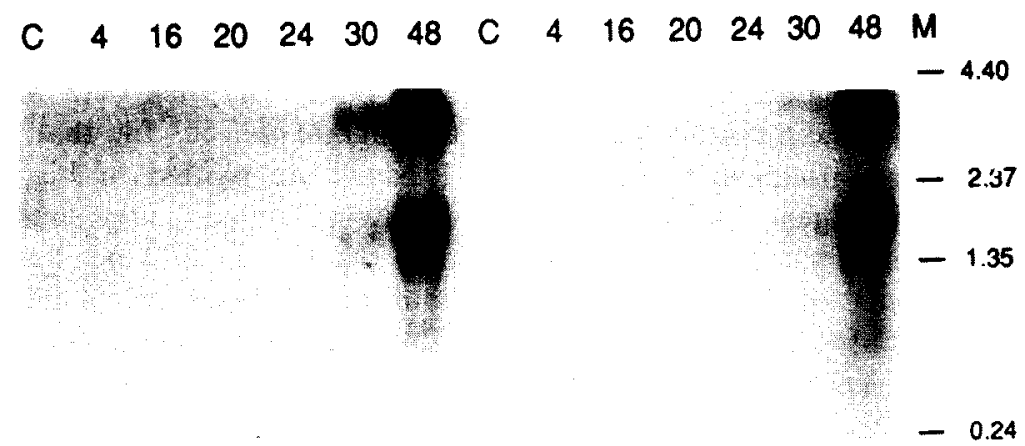

Fig. 3. Temporal Northern analysis of Ld $M N P V$ early, late, and hyper-expressed late genes. Total cellular RNA was harvested from Ld $M$ NPV infected Ld652Y cells at various times p.i., and hybridized with (A) a ${ }^{32}$ P-labelled oligonucleotide probe specific for G22 gene transcripts; (B) a ${ }^{32}$ P-labelled oligonucleotide probe specific for p39 capsid gene transcripts; and (C) a ${ }^{32} \mathrm{P}-\mathrm{labelled}$ oligonucleotide probe specific for polyhedrin gene transcripts. Viral isolates A21-2 and B21-1 were used for infections shown in Fig. sections A. B, and C. Numbers above the lanes indicate h p.i., the numbers on the right indicate the lengths (in kilobases) of marker RNAs, and lanes marked C contain RNA from mock-infected cells. 


\subsection{Temporal expression pattern of the LdMNPV DNA polymerase gene}

The temporal transcription pattern of the DNA polymerase gene was characterized to determine if the onset of this genes expression occurred at the same approximate time as the onset of viral DNA replication. A Northern blot containing RNA from Ld652Y cells infected with LdMNPV isolate A21-2 from 12 through $24 \mathrm{~h}$ p.i. was probed with a double-stranded DNA fragment that contained only DNA polymerase gene sequences since DNA polymerase gene transcripts were not detected using a stand-specific oligonucleotide probe. The DNA polymerase gene was first detected as a transcript of $\approx 3800$ bases in length at $16 \mathrm{~h}$ p.i., and was still expressed at $24 \mathrm{~h}$ p.i. (Fig. 5A). In order to confirm the identity of these transcripts, DNA polymerase gene expression was analyzed through reverse transcription and subsequent polymerase chain reaction (PCR) amplification. The reverse transcription reaction was performed with a nucleotide primer specific for DNA polymerase gene transcripts. A 562-bp DNA fragment would be generated in the PCR amplification. A fragment of approximately $562 \mathrm{bp}$ was found in

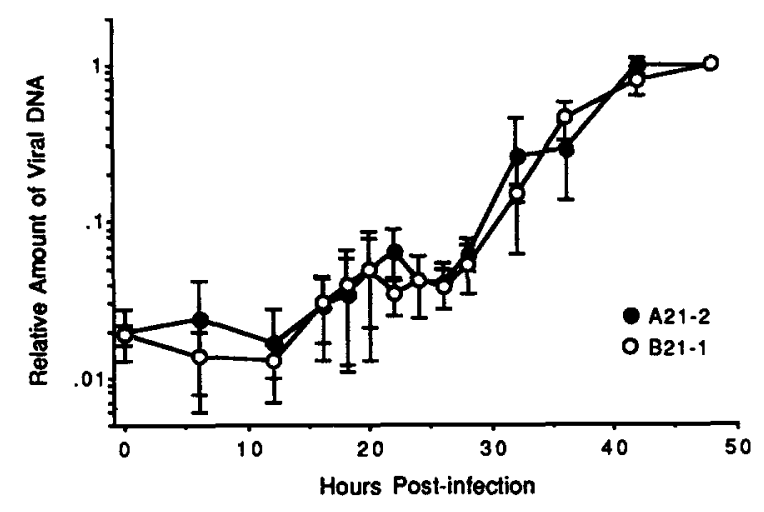

Fig. 4. Temporal accumulation of LdMNPV DNA during infection of Ld652Y cells at $10 \mathrm{TCID}_{50}$ units per cell. Relative amounts of isolates A21-2 and B21-1 were plotted versus time p.i. in hours. The amount of viral DNA present was determined by densitometric analysis of slot blot autoradiograms generated by hybridization of total cellular DNA with a ${ }^{32} \mathrm{P}$-labelled p39 capsid gene probe. Each value is the average of three replicate slot blots, and one standard deviation is shown.
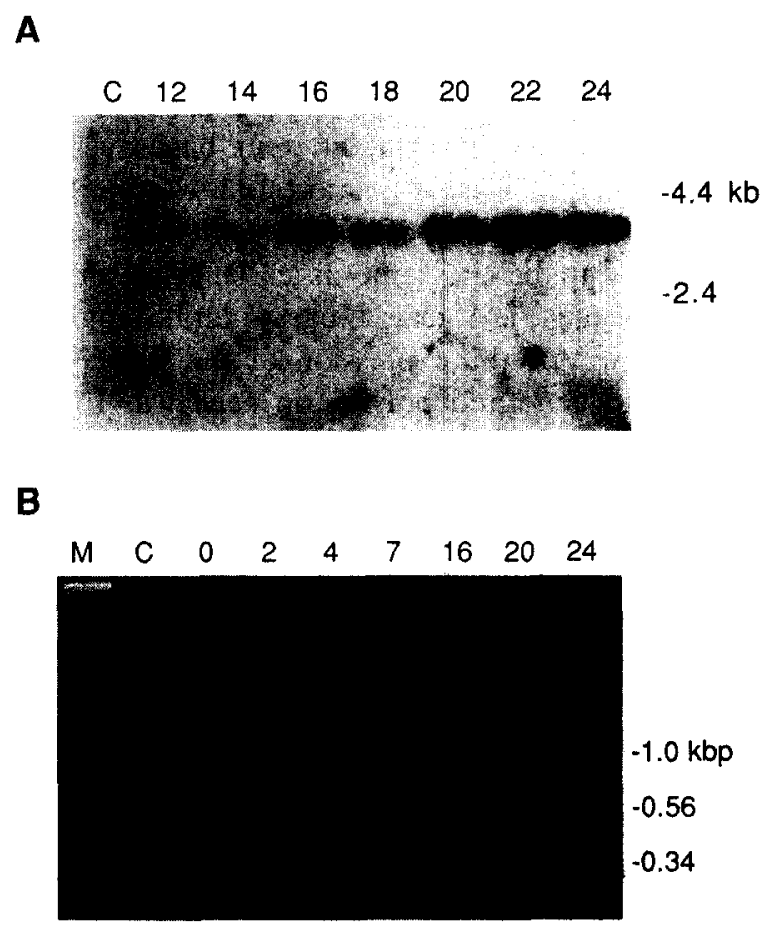

Fig. 5. Analysis of DNA polymerase gene transcription. Total cellular RNA was harvested from LdMNPV infected Ld652Y cells at various times p.i., and hybridized with a ${ }^{32} \mathrm{P}$-labelled DNA polymerase gene probe (A), or used to detect DNA polymerase gene transcripts through reverse transcription and subsequent polymerase chain reaction amplification (B). Numbers above the lanes indicate hours p.i., the numbers on the right indicate the lengths (in kilobases) of marker RNAs (A) or DNA fragments (B), and the lane marked C contains RNA from mock-infected cells.

the $7,16,20$, and $24 \mathrm{~h}$ p.i. samples (Fig. 5B). This result confirms the previous finding of DNA polymerase gene transcripts being present from 16 to $24 \mathrm{~h}$ p.i. However, it also indicates that DNA polymerase gene transcription occurs prior to the time when sufficient transcripts have accumulated to levels detectable by Northern analysis. Taken together these results suggest that DNA polymerase gene transcripts accumulate slowly during the early phase of infection. In the AcMNPV DNA polymerase gene transcripts are detectable 2 h p.i. (Tomalski et al., 1988) and the onset of viral replication occurs at approximately $6 \mathrm{~h}$ p.i. (Tjia et al., 1979). The later onset of DNA replication in LdMNPV may be a consequence of the slow 
accumulation of DNA polymerase gene transcripts.

While it is difficult to compare the temporal expression of genes from different baculoviruses in different cell lines, it is interesting to note that the onset of expression of the Ld $M$ NPV G22 gene was found to be the same as early genes in the AcMNPV (e.g., ie-1 gene, Guarino and Summers, 1987); however, the expression of the Ld $M$ NPV p39 capsid gene and polyhedrin gene was found to be significantly delayed compared to the expression of these genes in the AcMNPV which occurs at approximately $6 \mathrm{~h}$ p.i. (Friesen and Miller, 1985; Thiem and Miller, 1989). In addition, the onset of DNA replication $(18-20 \mathrm{~h}$ p.i.) and polyhedron formation ( $48 \mathrm{~h}$ p.i.) in the $\mathrm{Ld} M$ NPV were also found to be significantly delayed compared to the onset of DNA replication $(6 \mathrm{~h}$ p.i., Tjia et al., 1979) and polyhedron formation (12 h p.i.) in the AcMNPV. The onset of viral DNA replication (12 h p.i.) and polyhedron formation (48 h p.i.) in the Orgyia pseudotsugata (Bradford et al., 1990) is similar to what we have found in the $\mathrm{Ld} M \mathrm{NPV}$.

The longer replication cycle of the LdMNPV compared to the AcMNPV may be an evolutionary adaptation to the life cycle of its host. The gypsy moth host for LdMNPV takes approximately 45 to 56 days to pass from hatching to pupation (McManus, 1980). In contrast, the host of AcMNPV, Trichosplusia ni, takes about 17 days for larval development (Meade and Hare, 1991); and the alternate host Spodoptera frugiperda takes between 21 and 28 days (Ghidiu, 1987). A slower replicating Ld $M$ NPV would have an advantage, in the form of an increased number of progeny, due to the longer development time of the L. dispar host. Zanotto et al (1993) suggested that the Ld $M$ NPV and AcMNPV diverged from a common ancestor on the basis of polyhedrin gene phylogenetic relationships. The distinct rates of Ld $M$ NPV and AcMNPV replication may be a manifestation of their unique adaptive evolutionary paths. Comprehending the molecular basis of the regulation of $\mathrm{Ld} M$ NPV DNA replication may provide insights on viral evolutionary adaptation to a host.

\section{Acknowledgements}

The authors thank Dr George Rohrmann for the generous gift of the LdMNPV p39 capsid gene clone used in this investigation. They would also like to thank Dr Karen Garner and Dr David Bischoff for valuable discussion and critical reading of this manuscript. Also, they wish to gratefully acknowledge the technical assistance of Nancy Hayes-Plazolles and Mary Ellen Kelly. This research was supported by funds provided by the US Department of Agriculture, Forest Service, Northeastern Forest Experiment Station.

\section{References}

Ayres, M.D., Howard, S.C., Kuzio, J., Lopez-Ferber, M., Possee, R.D., 1994. The complete DNA sequence of Autographa californica nuclear polyhedrosis virus. Virology 202, $586-605$.

Bischoff, D.S., Slavicek, J.M., 1994. Identification and characterization of a protein kinase gene in the Lymantria dispar multinucleocapsid nuclear polyhedrosis virus. J. Virol. 68, $1728-1736$

Bischoff, D.S., Slavicek, J.M., 1995. Identification and characterization of an early gene in the Lymantria dispar multinucleocapsid nuclear polyhedrosis virus. J. Gen. Virol. 76 , 2933-2940.

Bjornson, R.M., Rohrmann, G.F., 1992a. Nucleotide sequence of the polyhedron envelope protein gene region of the Lymantria dispar nuclear polyhedrosis virus. J. Gen. Virol. 73, 1499-1504.

Bjornson, R.M., Rohrmann, G.F., 1992b. Nucleotide sequence of the p39-capsid gene region of the Lymantria dispar nuclear polyhedrosis virus. J. Gen. Virol. 73, 1505-1508.

Bjornson, R.M., Glocker, B., Rohrmann, G.F., 1992. Characterization of the nucleotide sequence of the Lymantria dispar nuclear polyhedrosis virus DNA polymerase gene region. J. Gen. Virol. 73, 3177-3183.

Blissard, G.W., Rohrmann, G.F., 1991. Baculovirus gp64 gene expression: Analysis of sequences modulating early transcription and transactivation by IEI. J. Virol. 65,5820 5827.

Blissard, G.W., Rohrmann, G.F., 1990. Baculovirus diversity and molecular biology. Ann. Rev. Entomol. 35, 127-155.

Bradford, M.B., Blissard, G.W., Rohrmann, G.F., 1990. Characterization of the infection cycle of the Orgyia pseudotsugata multinucleocapsid nuclear polyhedrosis virus in Lymantria dispar cells. J. Gen. Virol. 71, 2841-2846.

Brown, T., 1991. Dot and slot blotting of DNA. In: Ausubel F.M. et al. (Eds,), Current Protocols in Molecular Biology, 2.9.15-2.9.20 
David, W.A.L., 1975. The status of viruses pathogenic for insects and mites. Ann. Rev. Entomol, 20, 97-117.

Friesen, P.D., Miller, L.K., 1985. Temporal regulation of baculovirus RNA: overlapping early and late transcripts. J. Virol. 54, 392-400.

Ghidiu, G.M., 1987. Fall Armyworm. Fact sheet No. 285, Rutgers Cooperative Extension Service.

Glocker, B., Hoopes, R.R., Rohrmann, G.F., 1992. In vitro transactivation of baculovirus early genes by nuclear extracts from Autographa californica nuclear polyhedrosis virus-infected Spodoptera frugiperda cells. J. Virol. 66, 34763484.

Gombart, A.F., Pearson, M.N., Rohrmann, G.F., Beaudreau, G.S., 1989. A baculovirus polyhedral envelope-associated protein: Genetic location, nucleotide sequence, and immunocytochemical characterization. Virology 169, 182-193.

Guarino, L.A., Summers, M.D., 1986. Functional mapping of a trans- activating gene required for expression of a baculovirus delayed early gene. J. Virol. 57, 563-571.

Guarino, L.A., Summers, M.D., 1987. Nucleotide sequence and temporal expression of a baculovirus regulatory gene. $\mathrm{J}$. Virol. 61, 2091-2099.

Harrap, K.A., Payne, C.C., 1979. The structural properties and identification of insect viruses. Adv. Virus Res. 25, 273-355.

Mahmoudi, M., Lin, V.K., 1989. Comparison of two different hybridization systems in Northern transfer analysis. Biotechniques 7, 331-333.

McClintock, J.T., Dougherty, E.M., Weiner, R.M., 1986. Protein synthesis in gypsy moth cells infected with a nuclear polyhedrosis virus of Lymantria dispar. Virus Res. 5, 307322.

McManus, M.L., 1980. The Gypsy Moth. Forest Insect and Disease Leaflet 162. USDA Forest Service.

Meade, T., Hare, J.D., 1991. Different performance of beet armyworm and cabbage looper (lepidoptera:noctuidae) larvae on selected Apium graveolens cultivars. Environ. Entomol. 20, 1636-1644.

Nissen, M.S., Friesen, P.D., 1989. Molecular analysis of the transcriptional regulatory region of an early baculovirus gene. J. Virol. 63, 493-503.
Riegel, C.I., Lanner-Herrera, C., Slavicek, J.M., 1994. Identification and characterization of the ecdysteroid UDP-glucosyltransferase gene of the Lymantria dispar multinucleocapsid nuclear polyhedrosis virus. J. Gen. Virol. $75,829-838$

Rohrmann, G.F., 1992. Baculovirus structural proteins. J. Gen. Virol. 73, 749-761.

Slavicek, J.M., 1991. Temporal analysis and spatial mapping of Lymantria dispar nuclear polyhedrosis virus transcripts and in vitro translation polypeptides. Virus Res. 20, 223-236.

Slavicek, J.M., Hayes-Plazolles, N., Kelly, M.E., 1995. Rapid formation of few polyhedra mutants of Lymantria dispar multinucleocapsid nuclear polyhedrosis virus during serial passage in cell culture. Biol. Control 5, 251-261.

Smith, I.R.L., van Beek, N.A.M., Podgewaite, J.D., Wood, H.A., 1988. Physical map and polyhedrin gene sequence of Lymantria dispar nuclear polyhedrosis virus. Gene 71, 97105.

Strauss, W.M., 1990. Preparation of genomic DNA from mammalian tissue. In: Ausubel F.M. et al. (Eds.), Current Protocols in Molecular Biology, 2.2.1-2.2.3.

Thiem, S.M., Miller, L.K., 1989. Identification, sequence, and transcriptional mapping of the major capsid protein gene of baculovirus Autographa californica nuclear polyhedrosis virus. J. Virol. 63, 2008-2018.

Tinsley, T.W., Harrap, K.A., 1978. Viruses of invertebrates. Comprehensive Virol. 12, 1-101

Tjia, S.T., Carstens, E.B., Doerfler, W., 1979. Infection of Spodoptera frugiperda cells with Autographa californica nuclear polyhedrosis virus II: The viral DNA and the kinetics of its replication. Virology 99, 399-409.

Tomalski, M.D., Wu, J., Miller, L.K., 1988. The location, sequence, transcription, and regulation of a baculovirus DNA polymerase gene. Virology 167, 591-600.

Zanotto, P.M. de.A., Kessing, B.D., Maruniak, J.E., 1993. Phylogenetic interrelationships among baculoviruses: Evolutionary rates and host associations. J. Invertebrate Path. $62,147-164$ 